\title{
Penerapan Model Pembelajaran Tutor Sebaya untuk Meningkatkan Pemahaman dan Aktivitas Belajar Siswa pada Mata Pelajaran Pengolahan dan Penyajian Makanan Indonesia
}

\section{Ni Made Muliartini*}

SMKN 2 Singaraja

\author{
A R T I C L E I N F O \\ Article history: \\ Received 19 November \\ 2018 \\ Received in revised form \\ 30 December 2018 \\ Accepted 10 January 2019 \\ Available online 20 \\ February 2019 \\ Kata Kunci: \\ aktivitas belajar, \\ pemahaman, tutor sebaya \\ Keywords: \\ learning activities, \\ understanding, peer tutors
}

\begin{abstract}
A B S T RA K
Tujuan dari penelitian ini adalah untuk mengetahui peningkatan pemahaman dan aktivitas belajar siswa pada mata pelajaran Pengolahan dan Penyajian Makanan Indonesia kelas XI A 3 SMK Negeri 2 Singaraja tahun pelajaran 2017/2018 setelah diterapkannya model pembelajaran tutor sebaya. Penelitian ini adalah penelitian tindakan kelas. Subjek yang dijadikan sumber data dalam penelitian tindakan kelas ini adalah siswa kelas XI A 3 SMK Negeri 2 Singarja dengan jumlah siswa 36 orang terdiri dari 22 orang siswa laki-laki dan 14 orang siswa perempuan. Sedangkan objek penelitiannya adalah pemahaman dan aktivitas belajar siswa pada Mata Pelajaran Pengolahan dan Penyajian Makanan Indonesia pada materi menyiapkan dan membuat hidangan nasi dan mie dengan menggunakan model tutor sebaya. Data aktivitas belajar siswa dikumpulkan dengan menggunakan lembar observasi. Sedangkan data pemahaman belajar siswa menggunakan tes. Apabila data sudah terkumpul, dilanjutkan ke tahap analisis data dengan menggunakan analisis statistik deskriptif. Berdasarkan hasil penelitian yang telah dilaksanakan, maka dapat disimpulkan bahwa pemahaman dan aktivitas belajar siswa kelas XI A 3 SMK Negeri 2 Singaraja tahun pelajaran 2017/2018 secara efektif dapat ditingkatkan setelah diterapkannya model pembelajaran tutor sebaya.
\end{abstract}

\section{A B S T R A C T}

The purpose of this study was to determine the increase in students' understanding and learning activities in the subject of Indonesian Food Processing and Presentation in class XI A 3 of SMK Negeri 2 Singaraja in the academic year 2017/2018 after the application of peer tutoring learning models. This research is a classroom action research. Subjects that were used as the source of data in this classroom action research were students of class XI A 3 of SMK Negeri 2 Singarja with 36 students consisting of 22 male students and 14 female students. While the object of the research is understanding and learning activities of students in the Indonesian Food Processing and Presentation Subjects on the material preparing and making rice and noodle dishes using a peer tutor model. Student learning activity data is collected using an observation sheet. While the data on students' understanding of learning uses the test. If the data has been collected, proceed to the data analysis stage using descriptive statistical analysis. Based on the results of the research that has been carried out, it can be concluded that the understanding and learning activities of class XI A 3 students of SMK Negeri 2 Singaraja in the 2017/2018 school year can effectively be improved after the application of peer tutoring learning models. 


\section{Pendahuluan}

Pendidikan merupakan usaha sadar dan terencana untuk mewujudkan suasana belajar dan proses pembelajaran atau pelatihan agar peserta didik secara aktif dapat mengembangkan potensi dirinya secara terus menerus sepanjang hidup yang diharapkan dapat memiliki kekuatan spiritual keagamaan, emosional, pengendalian diri, kepribadian, kecerdasan, akhlak mulia, serta keterampilan yang diperlukan dirinya dan masyarakat. Pemerintah selalu berusaha untuk meningkatkan kualitas pendidikan dengan berbagai cara seperti mengganti kurikulum, meningkatkan kualitas guru melalui penataran-penataran, memberi dana Bantuan Operasional Sekolah (BOS) dan sebagainya. Pemerintah mengatur kebijakan pendidikan sesuai dengan fungsi dan tujuan Pendidikan Nasional dalam UU RI No. 20 tahun 2003 SISDIKNAS Bab II Pasal 3, yaitu "Pendidikan nasional berfungsi mengembangkan kemampuan dan membentuk watak serta peradaban bangsa yang bermartabat dalam rangka mencerdaskan kehidupan bangsa, bertujuan untuk berkembangnya potensi peserta didik agar menjadi manusia yang bertakwa kepada Tuhan YME, berakhlak mulia, sehat, berilmu, cakap, kreatif, mandiri dan menjadi warga negara yang demokratis serta bertanggug jawab".

Menghayati isi dari UU No. 20 tahun 2003 tersebut, peneliti berpendapat bahwa tugas seorang pendidik memang berat, sebab kemajuan suatu bangsa ditentukan oleh keberhasilan pendidikan dari bangsa itu sendiri. Jika seorang guru atau pendidik tidak berhasil mengembangkan potensi peserta didik maka negara itu tidak akan maju, sebaliknya jika guru atau pendidik berhasil mengembangkan potensi peserta didik, maka terciptalah manusia yang cerdas, terampil, dan berkualitas. Menurut Sanjaya (2006:19), peran guru adalah "Sebagai sumber belajar, fasilitator, pengelola, demonstrator, pembimbing, dan evaluator". Sebagai sumber belajar dan motivator guru harus mampu meningkatkan pemahanan dan membangkitkan motivasi siswa agar aktivitas proses pembelajaranberhasil dengan baik. Salah satu cara untuk meningkatkan pemahaman dan aktivitas siswa dalam proses pembelajaran adalah dengan mengganti model pembelajaran yang selama ini tidak diminati lagi oleh siswa, seperti pembelajaran yang dilakukan dengan ceramah dan tanya-jawab, model pembelajaran ini membuat siswa jenuh dan tidak kreatif. Suasana belajar mengajar yang diharapkan adalah menjadikan siswa sebagai subjek yang berupaya menggali sendiri, memecahkan sendiri masalah-masalah dari suatu konsep yang dipelajari, sedangkan guru lebih banyak bertindak sebagai motivator dan fasilitator. Situasi belajar yang diharapkan di sini adalah siswa yang lebih aktif.

Fenomena seperti diatas merupakan permasalahan yang perlu segera ditemukan alternatifalternatif pemecahannya. Salah satu upaya yang dapat dijadikan alternatif pemecahan masalah tersebut adalah dengan menerapkan pembelajaran yang meningkatkan pemahaman dan aktivitas belajar siswa melalui "model tutor sebaya (peer tutoring)" pada mata pelajaran pengolahan makanan Indonesia yang merupakan salah satu mata pelajaran produktif yang ada di SMK Tata Boga.Pada dasarnya Sekolah Menengah Kejuruan menciptakan peserta didik yang siap kerja, dalam upaya menyiapkan peserta didik yang handal dan memiliki kesiapan kerja, mereka dibekali dengan beberapa mata diklat yang dikelompokan menjadi 3 program yaitu program normatif, program adaptif, dan program produktif. Program produktif adalah kelompok mata diklat yang berfungsi membekali peserta didik agar memiliki kompetensi kerja sesuai Standar Kompetensi Kerja Nasional Indonesia (SKKNI). Oleh karena itu, dengan menggunakan model pembelajaran tutor sebaya pada mata pelajaran pengolahan makanan Indonesia, diharapkan peserta didik dapat lebih aktif dalam bertanya atau mengeluarkan pendapat, karena peserta didik tidak bertanya atau mengeluarkan pendapat langsung di dalam kelas, melainkan ke tutor dalam kelompoknya (Hasan, 2014). Pada pembelajaran tutor sebaya ini, sebagian peserta didik diajak untuk menjadi tutor atau sumber belajar dan tempat bertanya bagi temannya, sehingga bimbingan secara individu kepada peserta didik akan menjadi lebih optimal.

Berdasarkan uraian tersebut peneliti mencoba menerapkan salah satu model pembelajaran, yaitumodel pembelajaran tutor sebaya untuk mengungkapkan apakah dengan model pembelajaran tutor sebaya dapat meningkatkan pemahaman dan aktivitas belajar siswa dalam mata pelajaran pengolahan makanan Indonesia. Dari latar belakang tersebut maka penulis dalam penelitian ini mengambil judul "Penerapan Model Pembelajaran Tutor Sebaya Untuk Meningkatkan Pemahaman Dan Aktivitas Belajar Siswa Pada Mata Pelajaran Pengolahan Dan Penyajian Makanan Indonesia Kelas XI A 3 SMK Negeri 2 SingarajaTahun Pelajaran 2017/2018".

Pendidikan merupakan usaha sadar dan terencana untuk mewujudkan suasana belajar dan proses pembelajaran atau pelatihan agar peserta didik secara aktif dapat mengembangkan potensi dirinya secara terus menerus sepanjang hidup yang diharapkan dapat memiliki kekuatan spiritual keagamaan, emosional, pengendalian diri, kepribadian, kecerdasan, akhlak mulia, serta keterampilan yang diperlukan dirinya dan masyarakat. Pemerintah selalu berusaha untuk meningkatkan kualitas pendidikan dengan berbagai cara seperti mengganti kurikulum, meningkatkan kualitas guru melalui penataran-penataran, 
memberi dana Bantuan Operasional Sekolah (BOS) dan sebagainya. Pemerintah mengatur kebijakan pendidikan sesuai dengan fungsi dan tujuan Pendidikan Nasional dalam UU RI No. 20 tahun 2003 SISDIKNAS Bab II Pasal 3, yaitu:

Pendidikan nasional berfungsi mengembangkan kemampuan dan membentuk watak serta peradaban bangsa yang bermartabat dalam rangka mencerdaskan kehidupan bangsa, bertujuan untuk berkembangnya potensi peserta didik agar menjadi manusia yang bertakwa kepada Tuhan YME, berakhlak mulia, sehat, berilmu, cakap, kreatif, mandiri dan menjadi warga negara yang demokratis serta bertanggug jawab.

Menghayati isi dari UU No. 20 tahun 2003 tersebut, peneliti berpendapat bahwa tugas seorang pendidik memang berat, sebab kemajuan suatu bangsa ditentukan oleh keberhasilan pendidikan dari bangsa itu sendiri. Jika seorang guru atau pendidik tidak berhasil mengembangkan potensi peserta didik maka negara itu tidak akan maju, sebaliknya jika guru atau pendidik berhasil mengembangkan potensi peserta didik, maka terciptalah manusia yang cerdas, terampil, dan berkualitas. Menurut Sanjaya (2006:19), peran guru adalah "Sebagai sumber belajar, fasilitator, pengelola, demonstrator, pembimbing, dan evaluator". Sebagai sumber belajar dan motivator guru harus mampu meningkatkan pemahanan dan membangkitkan motivasi siswa agar aktivitas proses pembelajaranberhasil dengan baik (Indrianie, 2015). Salah satu cara untuk meningkatkan pemahaman dan aktivitas siswa dalam proses pembelajaran adalah dengan mengganti model pembelajaran yang selama ini tidak diminati lagi oleh siswa, seperti pembelajaran yang dilakukan dengan ceramah dan tanya-jawab, model pembelajaran ini membuat siswa jenuh dan tidak kreatif (Ulfah, 2018). Suasana belajar mengajar yang diharapkan adalah menjadikan siswa sebagai subjek yang berupaya menggali sendiri, memecahkan sendiri masalah-masalah dari suatu konsep yang dipelajari, sedangkan guru lebih banyak bertindak sebagai motivator dan fasilitator. Situasi belajar yang diharapkan di sini adalah siswa yang lebih aktif (Nurmiati, 2017).

Fenomena seperti diatas merupakan permasalahan yang perlu segera ditemukan alternatifalternatif pemecahannya. Salah satu upaya yang dapat dijadikan alternatif pemecahan masalah tersebut adalah dengan menerapkan pembelajaran yang meningkatkan pemahaman dan aktivitas belajar siswa melalui "model tutor sebaya (peer tutoring)" pada mata pelajaran pengolahan makanan Indonesia yang merupakan salah satu mata pelajaran produktif yang ada di SMK Tata Boga.Pada dasarnya Sekolah Menengah Kejuruan menciptakan peserta didik yang siap kerja, dalam upaya menyiapkan peserta didik yang handal dan memiliki kesiapan kerja, mereka dibekali dengan beberapa mata diklat yang dikelompokan menjadi 3 program yaitu program normatif, program adaptif, dan program produktif. Program produktif adalah kelompok mata diklat yang berfungsi membekali peserta didik agar memiliki kompetensi kerja sesuai Standar Kompetensi Kerja Nasional Indonesia (SKKNI). Oleh karena itu, dengan menggunakan model pembelajaran tutor sebaya pada mata pelajaran pengolahan makanan Indonesia, diharapkan peserta didik dapat lebih aktif dalam bertanya atau mengeluarkan pendapat, karena peserta didik tidak bertanya atau mengeluarkan pendapat langsung di dalam kelas, melainkan ke tutor dalam kelompoknya. Pada pembelajaran tutor sebaya ini, sebagian peserta didik diajak untuk menjadi tutor atau sumber belajar dan tempat bertanya bagi temannya, sehingga bimbingan secara individu kepada peserta didik akan menjadi lebih optimal.

Berdasarkan uraian tersebut peneliti mencoba menerapkan salah satu model pembelajaran, yaitumodel pembelajaran tutor sebaya untuk mengungkapkan apakah dengan model pembelajaran tutor sebaya dapat meningkatkan pemahaman dan aktivitas belajar siswa dalam mata pelajaran pengolahan makanan Indonesia. Dari latar belakang tersebut maka penulis dalam penelitian ini mengambil judul "Penerapan Model Pembelajaran Tutor Sebaya Untuk Meningkatkan Pemahaman Dan Aktivitas Belajar Siswa Pada Mata Pelajaran Pengolahan Dan Penyajian Makanan Indonesia Kelas XI A 3 SMK Negeri 2 SingarajaTahun Pelajaran 2017/2018".

\section{Metode}

Model penelitian ini adalah model penelitian tindakan kelas (action research). Proses penelitian tindakan kelas ini direncanakan berlangsung dalam dua siklus. Penelitian tindakan kelas ini dilaksanakan di SMK Negeri 2 Singaraja Lokasinya di Jalan Srikandi No. 9 Singaraja. Penelitian tindakan kelas ini kurang lebih dilaksanakan selama satu semester dimulai sejak minggu ketiga bulan Januari sampai akhir bulan Mei 2018.

Subjek yang dijadikan sumber data dalam penelitian tindakan kelas ini adalah siswa kelas XI A 3 SMK Negeri 2 Singarja dengan jumlah siswa 36 orang terdiri dari 22 orang siswa laki-laki dan 14 orang siswa perempuan. Sedangkan objek penelitiannya adalah aktivitas dan pemahaman belajar siswa pada Mata Pelajaran Pengolahan dan Penyajian Makanan Indonesia pada materi menyiapkan dan membuat hidangan nasi dan mie dengan menggunakan model tutor sebaya. 
Penelitian ini akan dilaksanakan dalam 2 siklus pembelajaran. Dimana masing-masing siklus pembelajaran terdiri dari empat tahap tindakan yaitu tahap perencanaan tindakan, pelaksanaan tindakan, observasi tindakan, dan tahap refleksi. Hasil refleksi digunakan sebagai penyempurnaan-penyempurnaan tindakan untuk siklus berikutnya, sedangkan refleksi yang digunakan pada siklus terakhir digunakan untuk membuat suatu rekomendasi-rekomendasi dari hasil peneitian ini.

Kegiatan di masing-masing siklus pada penelitian ini dapat digambarkan sebagai berikut.
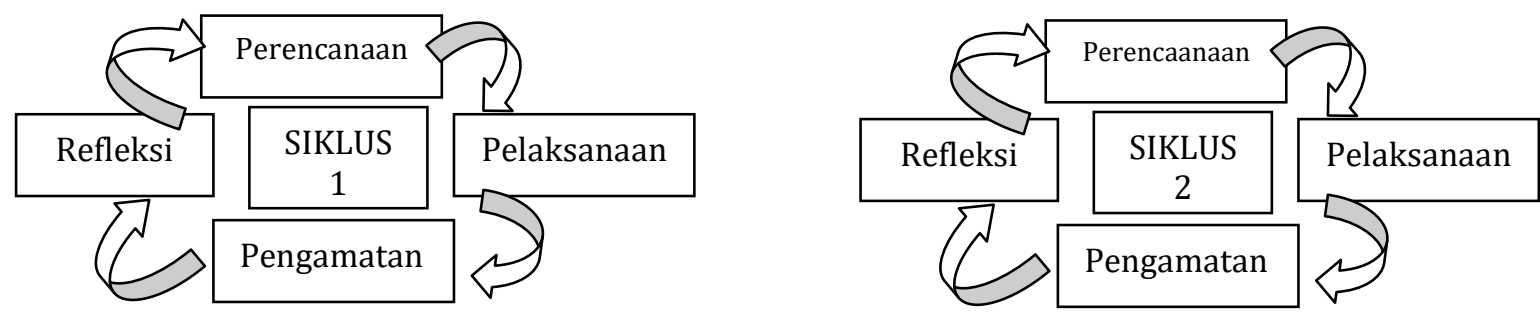

1. Siklus 1

Gambar 01. Siklus PTK

Siklus pertama dalam Penelitian Tindakan Kelas ini terdiri dari perencanaan, pelaksanaan, pengamatan dan refleksi sebagai berikut. A) Tahap Perencanaan (Planing), sebelum melaksanakan tindakan maka perlu tindakan persiapan. Kegiatan pada tahap ini adalah : 1) Menetapkan materi atau bahan ajar untuk 8 jam pelajaran @ 45 menit satu kali tatap muka, 2) Penyusunan RPP dengan model pembelajaran yang direncanakan dalam PTK, 3) Menentukan teknik pelaksanaan model pembelajaran yang akan dilaksanakan yaitu dengan menggunakan model pembelajaran tutor sebaya, 4) Membuat instrument yang akan digunakan yaitu dengan menyusun lembar tes yang akan digunakan untuk mengetahui tingkat pemahaman siswa, 5) Membuat instrument format observasi untuk melaksanakan pengamatan terhadap aktivitas belajar siswa pada kelompok besar, dan 6) Menyiapkan angket untuk mengetahui tanggapan peserta didik terhadap model pembelajaran tutor sebaya yang diaplikasi pada Penelitian Tindakan Kelas. B) Pelaksanaan (Acting),Pelaksanaan yang dilakukan sesuai dengan judul Penelitian Tindakan Kelas yaitu menerapkan model pembelajaran tutor sebaya, dimana skrenario kerja tindakan meliputi : 1) Guru menyampaikan materi mengenai menyiapkan dan membuat hidangan nasi dan mie, 2) Beberapa peserta didik yang pandai (tutor) disuruh mempelajari materi lebih lanjut, 3) Guru memberi penjelasan umum tentang materi yang akan dibahas kepada peserta didik, 4) Kelas dibagi ke dalam kelompok besar, yaitu terdiri dari 8 orang peserta didik dan diusahakan kelompok yang dibentuk tersebut adalah kelompok yang heterogen, 5) Peserta didik yang pandai (para tutor sebaya) disebar ke setiap kelompok untuk memberi bantuannya, 6) Guru memonitoring dan membimbing terus kapan tutor maupun peserta didik yang lain membutuhkan pertolongan. Guru memonitoring tutor dengan berkunjung dan menanyakan kesulitan yang dihadapi setiap kelompok pada saat mereka diskusi maupun praktikum di kelas, 7) Jika ada masalah, tutor memberitahu peserta didik yang kurang paham dan jika ada masalah yang tidak dapat terpecahkan, tutor dan peserta didiknya meminta bantuan kepada guru, 8) Penguatan dan kesimpulan secara bersama-sama, 9) Melakukan pengamatan dan observasi, 10) Guru mengadakan evaluasi. C) Pengamatan (Observation), Pengamatan dilakukan untuk melihat situasi belajar mengajar, kegiatan pengamatan observasi ini dilakukan bersama-sama dengan kegiatan pelaksanaan tindakan diatas. Pengamatan yang dilakukan terdiri dari : 1) Pemahaman siswa dalam mengidentifikasi produk nasi dan mie, 2) Aktivitas siswa dalam mengidentifikasi produk nasi dan mie, 3) Keberanian dalam menyampaikan pendapat, 4) Kemampuan mengaplikasikan model pembelajaran tutor sebaya. D) Refleksi (reflecting), Penelitian tindakan kelas ini dinilai berhasil apabila: 1) Meningkatnya pemahaman siswa dalam mengidentifikasi produk nasi dan mie, 2) Meningkatnyaaktivitas siswa dalam mengidentifikasi produk nasi dan mieyang dilihat setelah menggunakan model tutor sebaya, 3) Membagi dalam 8 kelompok untuk siklus berikutnya yaitu tiap kelompok terdiri dari $4-5$ orang. Refleksi dilakukan untuk mengamati pelaksanaan tindakan dan hasil penerapan model tutor sebaya pada siklus I, maka setelah terlihat dari hasil observasi perlu adanya perbaikan-perbaikan. Sehingga harus dilakukan siklus II dengan materi yang masih terkait dengan materi yang diberikan pada pelaksanaan di dalam siklus I yaitu menyiapkan dan membuat hidangan nasi dan mie. Kegiatan pada siklus II pada dasarnya sama dengan kegiatan pada siklus I hanya saja perencanaan kegiatan mendasarkan pada hasil refleksi pada siklus I sehingga lebih mengarah pada perbaikan pada pelaksanaan siklus II.

2. Siklus II

Seperti halnya siklus pertama, siklus kedua pun terdiri dari perencanaan, pelaksanaan, pengamatan/observasi dan refleksi. 
Data aktivitas belajar siswa dikumpulkan dengan menggunakan lembar observasi. Sedangkan data pemahaman belajar siswa menggunakan tes. Apabila data sudah terkumpul, dilanjutkan ke tahap analisis data dengan menggunakan analisis statistik deskriptif.

\section{Hasil dan Pembahasan}

Sebelum penelitian tindakan kelas ini dilaksanakan, peneliti mengadakan observasi dan pengumpulan data dari kondisi awal kelas yang akan diberikan tindakan, yaitu kelas XIA3 SMK Negeri 2 Singaraja tahun pelajaran 2017/2018.

Kondisi awal ini perlu diketahui agar kiranya penelitian ini sesuai dengan apa yang diharapkan oleh peneliti, apakah benar kiranya kelas ini perlu diberi tindakan yang sesuai dengan apa yang akan diteliti oleh peneliti yaitu penerapan model pembelajaran tutor sebaya untuk meningkatkan pemahaman dan aktivitas belajar siswa dalam menyiapkan dan membuat hidangan nasi dan mie mata pelajaran Pengolahan dan Penyajian Makanan Indonesia.

Untuk mengungkapkan kondisi awal dari kelas yang menjadi objek tindakan kelas ini maka peneliti melakukan langkah-langkah sebagai berikut:

1. Perencanaan

Untuk mengetahui kondisi awal dari kelas XI A3 SMK Negeri 2 Singaraja tahun pelajaran 2017/2018 maka terlebihdahulu peneliti merencanakan observasi pada kegiatan belajar mengajar yang dilakukan di kelas XI A 3 pada saat mata pelajaran Pengolahan dan Penyajian Makanan Indonesia berlangsung. Observasi ini dilakukan untuk mengetahui pemahaman dan aktivitas belajar siswa dengan menggunakan model pembelajaran yang pada umumnya di gunakan oleh guru, yaitu model pembelajaran ceramah.

2. Pelaksanaan

Pelaksanaan ini untuk mengukur kemampuan awal siswa, di awali dengan pengajaran yang dilakukan oleh guru mata pelajaran Pengolahan dan PenyajianMakanan Indonesia dengan menggunakan model pembelajaran ceramah. Pada pembelajaran ini peneliti mengamati kejadian-kejadian yang terjadi secara rinci pada saat guru menyampaikan materi pelajaran dan pada akhir pelajaran guru memberikan soal post test sebagai alat evaluasi.

3. Hasil Pengamatan

Berdasarkan observasi yang dilakukan oleh peneliti didapatkan bahwa pada pengajaran yang dilakukan, guru masih menggunakan cara pengajaran yang tradisional yaitu dengan menggunakan model pembelajaran ceramah. Pada pembelajaran berlangsung terlihat siswa asik dengan kegiatannya sendiri yang tidak ada kaitannya dengan apa yang disampaikan oleh guru. Terlihat peserta didik bermain-main dengan temannya tanpa memperdulikan apa yang disampaikan oleh guru pengajar.

Hasil tes yang dikerjakan oleh siswa pada soal post test yang telah dirancang oleh guru, setelah diadakan koreksi maka didapatkan hasil yang kurang memuaskan. Hasil koreksi tes awal dari 36 siswa yang ada di kelas XI A3 tersebut didapatkan hasil, 15 siswa mendapatkan nilai di bawah KKM, sedangkan siswa yang telah tuntas atau yang telah mendapatkan nilai di atas KKM berjumlah 21 siswa. Dari paparan hasil nilai yang didaptkan siswa, tampak bahwa yang mencapai ketuntasan belajar hanya 21 siswa atau hanya 58,33\% dari jumlah siswa yang ada di kelasXI A 3.

4. Refleksi

Bertolak dari kondisi awal tersebut, maka perlu diadakan suatu tindakan untuk meningkatkan kemampuan pemahaman materi dan aktivitas belajar siswa pada mata pelajaran Pengolahan dan Penyajian Makanan Indonesia. Berdasarkan kondisi awal, maka peneliti merencanakan tindakan penelitian dengan menerapkan model pembelajaran tutor sebaya di kelas XIA 3 SMK Negeri 2 Singaraja.

Penelitian tindakan kelas ini telah dilakukan sesuai dengan tahapan pelaksanaannya, yaitu rencana tindakan, pelaksanaan tindakan, observasi, dan refleksi. Peningkatan aktivitas belajar siswa pada saat pembelajaran pengolahan makanan Indonesia ditentukan dari 7 aspek yang terdapat dalam lembar observasi mengenai aktivitas belajar siswa. Dari total keseluruhan siswa yaitu sebanyak 36 orang pada siklu I dan siklus II di peroleh hasil sebagai berikut: 1) Peserta didik yang aktif mengajukan pertanyaan kepada tutornya dari $44 \%$ meningkat menjadi $86 \%$, 2) Peserta didik yang aktif menanggapi pertanyaan dari $17 \%$ meningkat menjadi 56\%, 3) Peserta didik yang aktif menyampaikan pendapat di depan teman sebayanya dari $14 \%$ meningkat menjadi 50\%, 4) Peserta didik yang aktif berdiskusi bersama teman satu kelompoknya dari $86 \%$ meningkat menjadi $100 \%$, 5) Peserta didik yang aktif memperhatikan materi yang disampaikan oleh tutornya dari $61 \%$ meningkat menjadi $86 \%$, 6) Peserta didik yang aktif menulis hal-hal yang penting pada materi yang telah disampaikan oleh tutor dari 50\% meningkat menjadi $86 \%$, dan 7) Peserta didik yang aktif melakukan tugas-tugas sesuai dengan yang diminta oleh tutor atau gurunya sebanyak $100 \%$ baik di siklus I maupun di siklus II. 
Data hasil pemahaman belajar siswa menunjukkan bahwa pemahaman belajar siswa terhadap pembelajaran pengolahan makanan Indonesia mengenai menyiapkan dan membuat hidangan nasi dan mie meningkat menjadi sangat baik.Hal ini dapat dilihat dari hasil post test yang telah dilaksanakan di siklus I dan siklus II, siswa yang sudah tuntas dalam belajar dari 20 orang menjadi 36 orang, siswa yang sudah tuntas dalam belajar meningkat menjadi 100\% yaitu sebanyak 36 orang. Dengan uraian sebagai berikut: peserta didik yang memperoleh predikat A dengan perolehan skor rerata3.85 - 4.00 yang semula berjumlah 2 orang meningkat menjadi 6 orang, peserta didik yang memperoleh predikat A- dengan perolehan skor rerata 3.51 - 3.84 yang mulanya berjumlah 8 orang menjadi 7 orang, peserta didik yang memperoleh predikat B+dengan perolehan skor rerata3.18- 3.50 yang asalnya berjumlah 6 orang meningkat menjadi 15 orang, peserta didik yang memperoleh predikat B dengan prolehan skor rerata 2.85 - 3.17 yang mulanya 5 orang meningkat menjadi 8 orang dan tidak ada siswa yang belum tuntas.Nilai rata - rata pada siklus I sebesar 73,19\% meningkat menjadi 86,25\%. Jadi dengan menggunakan modelTutor Sebaya (peer tutoring) nilai rata - rata siswa kelas XIA 3 Semester 2 SMK Negeri 2 Singaraja Tahun Pelajaran 2017/2018 meningkat 13.06\%.

\section{Simpulan dan Saran}

Berdasarkan hasil penelitian yang telah dilaksanakan, maka dapat disimpulkan bahwa aktivitas belajar siswa dalam mata pelajaran Pengolahan dan Penyajian Makanan Indonesia mengenai menyiapkan dan membuat hidangan nasi dan mie menunjukkan kriteria sangat aktif yaitumengajukan pertanyaan kepada tutor sebanyak 86\%, berdiskusi bersama teman satu kelompok sebanyak 100\%, memperhatikan materi yang disampaikan oleh tutor sebanyak 86\%,menulis hal-hal yang penting pada materi yang telah disampaikan oleh tutor sebanyak 86\%, melakukan tugas-tugas sesuai dengan yang diminta oleh tutor atau gurunya sebanyak $100 \%$.

Data hasil pemahaman belajar siswa menunjukkan bahwa pemahaman belajar siswa terhadap pembelajaran Pengolahan dan Penyajian Makanan Indonesia mengenai menyiapkan dan membuat hidangan nasi dan mie meningkat menjadi sangat baik.Hal ini dapat dilihat dari hasil post test yang telah dilaksanakan di siklus I dan siklus II, siswa yang sudah tuntas dalam belajar dari 21 orang (58,33 \%) pada siklus I menjadi 36 orang (100\%) pada sikluis II. Dengan uraian sebagai berikut: peserta didik yang memperoleh predikat A dengan perolehan skor rerata 3.85 - 4.00 yang asalnya berjumlah 2 orang meningkat menjadi 6 orang, peserta didik yang memperoleh predikat A- dengan perolehan skor rerata 3.51 - 3.84 yang asalnya berjumlah 8 orang menjadi 7 orang, peserta didik yang memperoleh predikat $\mathrm{B}+$ dengan perolehan skor rerata 3.18-3.50 yang asalnya berjumlah 6 orang meningkat menjadi 15 orang, peserta didik yang memperoleh predikat B dengan prolehan skor rerata 2.85 - 3.17 yang asalnya 5 orang meningkat menjadi 8 orang dan tidak ada siswa yang belum tuntas dalam belajar. Nilai rata - rata yang diperoleh pada siklus I sebesar 73,19\%, meningkat pada siklus II menjadi 86,25\%. Jadi dengan menggunakan model Tutor Sebaya (peer tutoring) nilai rata - rata siswa meningkat 13,06\%.

Berdasarkan hasil penelitian di atas, peneliti mempunyai beberapa saran yaitu (1) pembelajaran Model Tutor Sebaya bias dijadikan sebagai salah satu alternatif pembelajaran pengolahan makanan Indonesia selanjutnya; (2) jika menggunakan model tutor sebaya maka dibutuhkan perencanaan yang baik dan pengelolaan waktu yang tepat; (4) sebelum menerapkan model tutor sebaya, terlebih dahulu guru harus mengetahui kemampuan siswa, sehingga tidak salah ketika akan memilih siswa untuk menjadi tutor.

\section{Daftar Rujukan}

Arikunto, Suharsimi. 2006. Prosedur Penelitian Suatu Pendekatan Praktik. Jakarta: Rineka Cipta.

Daryanto. 2008. Evaluasi Pendidikan. Jakarta. Rineka Cipta.

Hasan, S.A., Handayani, M.M. and Psych, M., 2014. Hubungan antara dukungan sosial teman sebaya dengan penyesuaian diri siswa tunarungu di sekolah inklusi.Jurnal Psikologi Pendidikan dan Perkembangan, 3(2), pp.128-135.

Indrianie, N.S., 2015. Penerapan model tutor sebaya pada mata pelajaran bahasa inggris reported speech terhadap hasil belajar peserta didik MAN Kota Probolinggo. Jurnal Kebijakan dan Pengembangan Pendidikan, 3(1). 
Kurniawan, R.I. and Jaedun, A., 2018. Penerapan Metode Tutor Sebaya untuk Meningkatkan Motivasi dan Hasil Belajar Siswa pada Mata Pelajaran Estimasi Biaya Konstruksi dan Properti SMK N 2 Wonosari. E-Journal Pend. Teknik Sipil Dan Perencanaan, 6(4), pp.32-42.

Nurmiati, N. and Mantasiah, R., 2017. Keefektifan Penggunaan Metode Pembelajaran Tutor Sebaya (PeerTeaching) Dalam Kemampuan Membaca Memahami Bahasa Jerman Siswa Kelas XI IPA SMA Negeri 1 Bontonompo Kabupaten Gowa. Eralingua: Jurnal Pendidikan Bahasa Asing dan Sastra, 1(1).

Sarini, N.K., Sudana, D.N. and Riastini, P.N., 2018. Hasil Belajar Ipa Kelas IV SD di Gugus II Santalia Melalui Tutor Sebaya. Jurnal Ilmiah Sekolah Dasar, 2(2), pp.94-102.

Sanjaya, Wina. 2009. Strategi Pemebelajaran Berorientasi Standar Proses Pendidikan. Jakarta: Kencana.

Sardiman. 2007. Interaksi \& Motivasi Belajar Mengajar. Bandung: Raja Grafindo Persada.

Sudjana, Nana. 2010. Penilaian Hasil Proses Belajar Mengajar. Bandung: Remaja Rosdakarya.

Ulfah, A.N. and Ariati, J., 2018. Hubungan Dukungan Teman Sebaya Dengan Motivasi Berprestasi Pada Santri Pesantren Islam Al-Irsyad, Kecamatan Tengaran, Kabupaten Semarang. Empati, 6(4), pp.297301.

Wati, L. and Anafiah, S., 2018. Implementasi Strategi Pembelajaran Tutor Sebaya Pada Anak Berkesulitan Belajar Khusus Di Sd Taman Muda Ibu Pawiyatan Taman siswa. Trihayu: Jurnal Pendidikan Ke-SDan, 5(1). 